\title{
Influence of the vinasse application in sugar cane fields in Patrocínio Paulista, São Paulo State, Brazil
}

\author{
A. Waal ${ }^{1}$, J. R. Jiménez-Rueda ${ }^{2}$, D. M. Bonotto ${ }^{2}$, C. Bertelli ${ }^{2}$, \\ H. M. Hoffmann ${ }^{1}$, E. Foßhag ${ }^{1} \&$ M. Santilli ${ }^{2}$ \\ ${ }^{1}$ Fakultät für Verfahrens- und Chemietechnik, Hochschule Mannheim, \\ Germany \\ ${ }^{2}$ Departamento de Petrologia e Metalogenia, \\ Instituto de Geociências e Ciências Exatas-UNESP, Brazil
}

\begin{abstract}
This investigation was carried out in Patrocínio Paulista municipality, located in the state of São Paulo, Brazil. Sugarcane has been extensively cultivated in the area in order to be utilized by the sugar and ethanol industries. The major effluent from the ethanol industry, vinasse, has been applied in the sugarcane fields as an alternative to supply several nutrients in crop production. Because it may represent a major environmental problem in that area, with implications to human health, soil samples from six points were collected and analyzed in order to evaluate the main factors related to the vinasse application in the ground. The importance of clays, iron oxides, organic matter and minor refractory minerals was also considered for explaining several relationships identified from the acquired data.

Keywords: soil contamination, vinasse, sugar and alcohol production, ${ }^{40} \mathrm{~K}$ radioactivity, sugar cane fields, São Paulo State.
\end{abstract}

\section{Introduction}

In Brazil, waste disposal areas related to the production and processing of sugarcane may be a source of contaminants to the environment, mainly soils and underground hydrological resources. São Paulo is the most populous Brazilian state, comprising $\sim 40$ million inhabitants distributed over 645 municipalities. It 
has the highest number of industries and economic production, reaching $31 \%$ of the Brazilian gross domestic product (GDP). Despite the vigorous industrial production that includes high technology goods, the state is also well developed in agriculture and cattle breeding [1]. This advanced stage of agricultural and industrial growth causes São Paulo State a great diversity of problems related to the interaction between the society and the environment.

Considering the central, southeastern and southern Brazilian regions, the number of units responsible for the production and processing of sugarcane are: 49- São Paulo State; 23- Paraná State; 8- Mato Grosso do Sul State; 5- Minas Gerais State; 5-Mato Grosso State; 4- Goiás State; 2- Espírito Santo State; 1- Rio de Janeiro State [2]. During 2007, the sugarcane production in these states reached 375 million tons, whose processing yielded 17.2 billion liters of alcohol and 23.7 million tons of sugar [3]. Thus, São Paulo State was responsible for almost $50 \%$ of this production.

The disposal of vinasse, the major effluent from the ethanol industry, represents a major environmental problem in São Paulo State. Vinasse is a final byproduct of the sugar industry. Sugar beet is processed to produce crystalline sugar, pulp and molasses. The latter are further processed by fermentation to alcohol. After the removal of the alcohol by distillation the remaining material is vinasse. Molasses is a thick syrup by-product from the processing of the sugarcane or sugar beet into sugar [4]. To make molasses, which is pure sugar cane juice, the sugar cane plant is harvested and stripped of its leaves. Its juice is extracted from the canes, usually by crushing or mashing. The juice is boiled to concentrate and promote the crystallization of the sugar. Cane molasses is a common ingredient in baking, often used in baked goods such as gingerbread cookies.

Vinasse is a black liquid consisting of a mixture of water and organic and inorganic compounds that remain after different steps involving the sugar cane production and processing. It is produced at a rate 10 to 15 times greater than the ethanol itself, i.e. in terms of volume, approximately $13 \mathrm{~L}$ of vinasse are produced for each L of alcohol obtained from cane must $[5,6]$. Considering the high amount of alcohol produced by São Paulo State during 2007, the generation of about 100 billion liters of vinasse may be estimated, which represents an enormous volume to be released into the environment.

Vinasse compounds may also be a FOG (fats, oil and grease) source and are considered hazardous substances because they have a very high Biological Oxygen Demand (BOD) (30-40,000 mg/L) and $\mathrm{pH}$ between 4 and 5 [5]. Thus, vinasse is a highly corrosive residue and research has demonstrated that its disposal in river basins alone is not a convenient disposal solution. Due to its high BOD, this material can cause damage to aquatic life, especially when dumped in large volumes [7,8].

Another important aspect is among the factors affecting sugarcane productivity is fertilization. However, mineral fertilizers have significantly increased in price. As a result, it has become necessary to seek alternatives that would supply the soil with more economic nutrients. Because vinasse has high levels of potassium, calcium and organic matter in its chemical composition as well as moderate amounts of magnesium, nitrogen and phosphorus $[5,6]$ it has represented an alternative to supply 
such nutrients in crop production, as has been reported by various research works documenting an increase in sugarcane productivity, mainly in Brazil [9, 10]. However, the problem occurs when some soils do not respond positively to the application of this acid material.

The potential health hazard from natural ${ }^{40} \mathrm{~K}$ radionuclide is among the aspects that have been considered worldwide in dose calculations, with many countries also adopting guideline activity concentration values for food and drinking water. However, the measurements of this radionuclide in soils contaminated with vinasse in Brazil are scarce because, in general, they require specialized training and instrumentation.

This paper describes the results of some soil monitoring held in Patrocínio Paulista, São Paulo State, Brazil, where agricultural activities related to the sugarcane production has been conducted for several years. Because vinasse has also been extensively applied in the area for increasing the soil productivity, it is as well reported ${ }^{40} \mathrm{~K}$ data in soils that have received this effluent. The importance of weathering processes that have produced clays, iron oxides and minor refractory minerals in soils has also been considered for explaining several relationships identified from the acquired data.

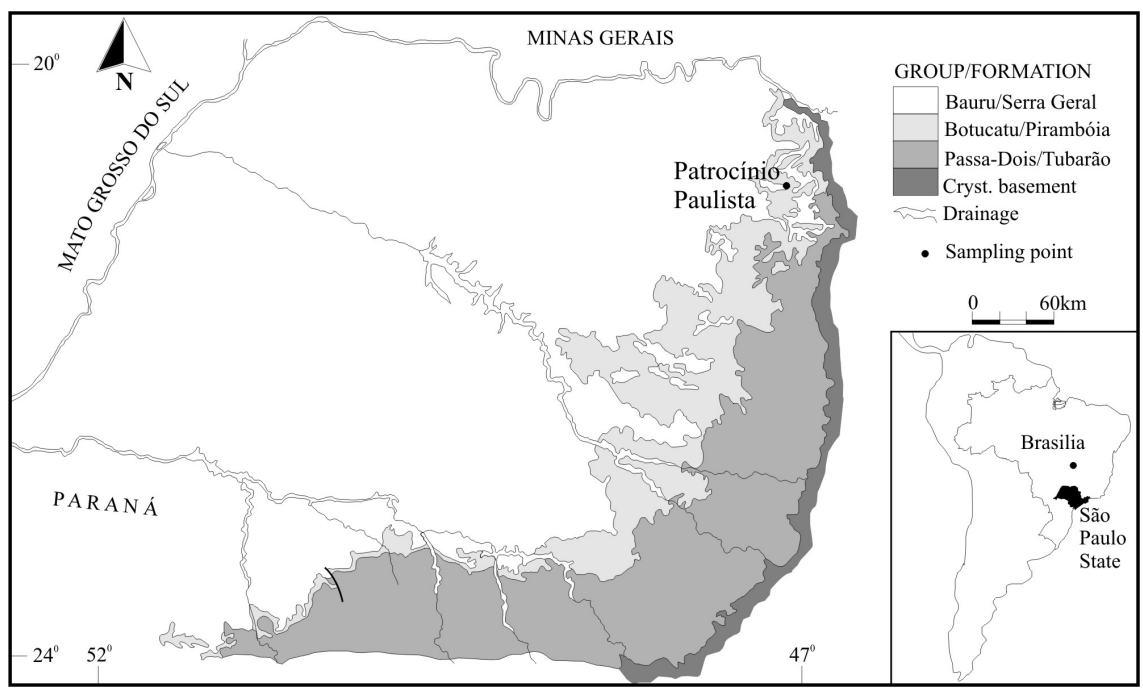

Figure 1: A simplified geological map of São Paulo State, Brazil, and the location of the sampling point for soil analyses. Modified from [11].

\section{General features of the area studied}

The studied area is situated in the rural zone of Patrocínio Paulista city that is about $410 \mathrm{~km}$ distant from São Paulo city, the capital of São Paulo State. It is located at $20^{\circ} 37^{\prime} 48^{\prime \prime} \mathrm{S}$ and $47^{\circ} 16^{\prime} 48^{\prime \prime} \mathrm{W}$ (Fig. 1), the altitude is $800 \mathrm{~m}$ above sea 
level, the surface area of the municipality is $\sim 610 \mathrm{~km}^{2}$, the population is $\sim 12,000$ inhabitants, and the cerrado fields dominate the landscape of the region [12]. The major economic activities of the municipality involve the agro business, with dominance of coffee and sugarcane production [12].

The area studied is geologically situated at the giant Paraná sedimentary basin that extends over an area of 1.7 million $\mathrm{km}^{2}$ ( 1 million $\mathrm{km}^{2}$ in Brazilian surface) [13]. Some of these stratigraphic units of the Paraná basin (Paleozoic - Cenozoic) crop-out in it [zz] (Fig. 1): the Tubarão Group comprising the Itararé Subgroup (sandstones, conglomerates, diamictites, tillites, siltstones, shales and rythmites) and Tatuí Formation (siltstones, shales, silex and sandstones with local concretions); the Passa Dois Group comprising the Irati Formation (siltstones, mudstones, black betuminous shales and limestones) and Corumbataí Formation (mudstones, shales and siltstones); the São Bento Group comprising the Pirambóia Formation (sandstones, shales and muddy sandstones), Botucatu Formation (sandstones and muddy sandstones), Serra Geral Formation (basalts and diabases) and related basic intrusives; different types of Cenozoic covers like the recent deposits, terrace sediments and others formations comprising sandstones, conglomerate sandstones, muddy sandstones, etc.

\section{Material and methods}

This study provided chemical data for soil samples collected in 6 points located at the rural zone of Patrocínio Paulista, where sugarcane has been cultivated and vinasse has been added in order to increase its production. Two samples were collected from each point: one between 0 and $20 \mathrm{~cm}$ depth and another between 20 and $60 \mathrm{~cm}$ depth. One sampling point (A6) corresponded to a site where there was no application of vinasse (the control). Approximately $5 \mathrm{~kg}$ of material was collected from the two depths in each sampling point with a manual sampler, described/classified (Table 1) and transferred to a thick polyethylene bag. Then, all bags containing the soil samples were transported to LABIDRO (Laboratory of Isotopes and Hydrochemistry) of Petrology Department from Geosciences and Exacts Sciences Institute that belongs to UNESP, situated at Rio Claro city, about $240 \mathrm{~km}$ distant from the investigated area.

The soils were dried at $60^{\circ} \mathrm{C}$, crushed, quartered, sieved for detailed grain size determination and divided into aliquots for different analyses. The dominant size class of the soil samples was medium sand, except A6 that corresponded to very coarse sand (Table 2). The total organic matter content was evaluated by spectrophotometry [14] held in a solution obtained after adding potassium dichromate and sulfuric acid to $1 \mathrm{~g}$ powdered aliquot; organic carbon was oxidized to carbon dioxide with a parallel reduction of hexavalent chromium to trivalent chromium and an accompanying color change from orange to green read at $610 \mathrm{~nm}$ [14]. The organic carbon was estimated from those readings by the Walkley-Black method [15].

The major oxides were determined in one $5 \mathrm{~g}$ aliquot by the X-ray fluorescence method. The chemical balance (in percentage) also supplied data on the loss on ignition (LOI), as the measurements involved weight loss of the 
Table 1: Description of the soil samples collected in Patrocínio Paulista, São Paulo State, Brazil.

\begin{tabular}{|c|c|c|c|}
\hline $\begin{array}{l}\text { Sample } \\
\text { Code }\end{array}$ & $\begin{array}{l}\text { Depth } \\
\text { (cm) }\end{array}$ & Color[16] & Description \\
\hline A1 & $0-20$ & $\begin{array}{l}2,5 Y R 3 / 2 \\
\text { dusky red }\end{array}$ & $\begin{array}{l}\text { Medium/coarse clay loam; sub-angular/angular vey } \\
\text { fine/medium hyaline quartz with hematite in } \\
\text { fractures; medium/coarse angular magnetite from } \\
\text { diabase. }\end{array}$ \\
\hline A1 & $20-60$ & $\begin{array}{l}2,5 \mathrm{YR} 3 / 1 \\
\text { dark red- } \\
\text { dish gray }\end{array}$ & $\begin{array}{l}\text { Medium/coarse plastic/concretionary sandy clay } \\
\text { loam; sub-angular/angular vey fine/medium } \\
\text { translucid quartz; some angular ferruginated fibers; } \\
\text { sub-angular medium magnetite; soil } \\
\text { concretions/pebbles. }\end{array}$ \\
\hline $\mathrm{A} 2$ & $0-20$ & $\begin{array}{l}2,5 \mathrm{YR} 2,5 / 2 \\
\text { very dusky } \\
\text { red }\end{array}$ & $\begin{array}{l}\text { Medium/coarse sandy clay loam; clear/limpid fine } \\
\text { rounded quartz; fine/medium sub-angular magnetite. }\end{array}$ \\
\hline $\mathrm{A} 2$ & $20-60$ & $\begin{array}{l}\text { 10R3/2 } \\
\text { dusky red }\end{array}$ & $\begin{array}{l}\text { Sandy clay loam; fine/medium sub- } \\
\text { rounded/rounded concretions/quartz, with hematite } \\
\text { present in some quartz; soil concretions with quartz. }\end{array}$ \\
\hline A3 & $0-20$ & $\begin{array}{l}\text { 10R3/2 } \\
\text { dusky red }\end{array}$ & $\begin{array}{l}\text { Fine/medium sandy clay; limpid and sub-rounded } \\
\text { fine/medium quartz with some ferruginated in } \\
\text { fractures; bi-pyramidal quartz related to granitic } \\
\text { source }\end{array}$ \\
\hline A3 & $20-60$ & $\begin{array}{l}2,5 \mathrm{YR} 3 / 2 \\
\text { dusky red }\end{array}$ & $\begin{array}{l}\text { Fine/medium sandy clay loam; fine/medium well } \\
\text { rounded ferruginated quartz; coarse angular } \\
\text { magnetite; fine/medium soil concretions with } \\
\text { quartz. }\end{array}$ \\
\hline A4 & $0-20$ & $\begin{array}{l}2,5 \mathrm{YR} 2,5 / 3 \\
\text { dark red- } \\
\text { dish brown }\end{array}$ & $\begin{array}{l}\text { Medium sandy clay loam; fine rounded and sub- } \\
\text { angular clear quartz with hematite in fractures of } \\
\text { some of them; concretions of variable size, } \\
\text { dominantly fine. }\end{array}$ \\
\hline A4 & $20-60$ & $\begin{array}{l}2,5 Y R 3 / 2 \\
\text { dusky red }\end{array}$ & $\begin{array}{l}\text { Fine/medium sandy clay loam; fine slightly plastic } \\
\text { and massif lateritic concretion that breaks into small } \\
\text { fragments; nodular concretions of } \sim 0.5 \mathrm{~cm} \text {. }\end{array}$ \\
\hline A5 & $0-20$ & $\begin{array}{l}\text { 10R3/4 } \\
\text { dusky red }\end{array}$ & $\begin{array}{l}\text { Medium/coarse sandy clay loam; anaerobic ancient } \\
\text { mica roots; fine concretionary translucid and clear } \\
\text { sub-angular/rounded quartz related to Marília, } \\
\text { Pirambóia and Formations. }\end{array}$ \\
\hline A5 & $20-60$ & $\begin{array}{l}\text { 10R3/2 } \\
\text { dusky red }\end{array}$ & $\begin{array}{l}\text { Coarse sandy clay; anaerobic ancient mica roots; } \\
\text { sub-rounded translucid quartz }(>5 \%) \text {; fine lateritic } \\
\text { concretion; soil gravel concretionary/pebbles } \sim 0.5 \text { - } \\
1 \mathrm{~cm}\end{array}$ \\
\hline A6 & $0-20$ & $\begin{array}{l}2,5 \mathrm{YR} 3 / 2 \\
\text { dusky red }\end{array}$ & $\begin{array}{l}\text { Medium fibrous sandy clay loam; fine } \\
\text { concretionary/ medium sub-rounded; sub- } \\
\text { rounded/rounded hyaline quartz ferruginated in } \\
\text { fractures; sub-rounded magnetite }\end{array}$ \\
\hline A6 & $20-60$ & $\begin{array}{l}2,5 \mathrm{YR} 3 / 3 \\
\text { dark red- } \\
\text { dish brown }\end{array}$ & $\begin{array}{l}\text { Medium/coarse concretionary clay loam; } 1-5 \mathrm{~mm} \\
\text { sub-angular/sub-rounded concretions; very fine } \\
\text { limpid and sub-rounded quartz; fine rounded } \\
\text { concretions. }\end{array}$ \\
\hline
\end{tabular}


samples after their burning at selected temperatures. Thus, LOI provided another (indirect) evaluation of the organic matter content in the soil samples, because it expresses the organic matter + adsorbed water + water in crystal lattices and fluid inclusions $+\mathrm{CO}_{2}$ of carbonates $+\mathrm{SO}_{2}$ of sulfides.

The exchangeable (mobile) potassium, aluminum and iron were evaluated on utilizing a $50 \mathrm{~g}$ aliquot of each soil sample and $100 \mathrm{~mL}$ of $0.1 \mathrm{M} \mathrm{HCl}$ as extractant. The amount of metals extracted was estimated colorimetrically by Hach DR/2000 spectrophotometer [14]. The tetraphenylborate method was used for measuring potassium, read at $650 \mathrm{~nm}$. The aluminon method that utilizes ascorbic acid provided the measurements for aluminum, read at $522 \mathrm{~nm}$. The 1,10 phenanthroline indicator formed an orange color in proportion to the iron concentration, which was read at $510 \mathrm{~nm}$.

Table 2: $\quad$ Results of the grain size analyses (percentual values) in soil samples collected in Patrocínio Paulista, São Paulo State, Brazil.

\begin{tabular}{cccccccccccc}
\hline & & \multicolumn{7}{c}{ Grain size $(\mathrm{mm})$} & \\
\cline { 3 - 10 } Sample & $\begin{array}{c}\text { Depth } \\
\text { Code }\end{array}$ & $\begin{array}{c}\text { Range } \\
(\mathrm{cm})\end{array}$ & 1.19 & 0.71 & 0.35 & 0.25 & 0.149 & 0.062 & 0.020 & & $\begin{array}{c}\text { Dominant } \\
\text { Class }\end{array}$ \\
\hline A1 & $0-20$ & 12.5 & 7.1 & 7.9 & 23.1 & 17.1 & 15.0 & 9.6 & 7.7 & MS \\
A1 & $20-60$ & 12.1 & 7.7 & 9.6 & 25.5 & 17.8 & 14.2 & 9.2 & 3.7 & MS \\
A2 & $0-20$ & 11.4 & 7.7 & 9.5 & 23.9 & 14.2 & 14.2 & 9.6 & 9.5 & MS \\
A2 & $20-60$ & 13.2 & 8.3 & 9.3 & 23.5 & 13.5 & 13.5 & 8.9 & 9.6 & MS \\
A3 & $0-20$ & 6.7 & 6.3 & 7.5 & 20.3 & 12.6 & 16.7 & 18.7 & 11.2 & MS \\
A3 & $20-60$ & 15.1 & 8.6 & 9.5 & 24.4 & 12.7 & 14.3 & 8.5 & 6.5 & MS \\
A4 & $0-20$ & 11.6 & 6.8 & 5.9 & 26.2 & 12.3 & 15.2 & 10.7 & 11.1 & MS \\
A4 & $20-60$ & 12.3 & 8.1 & 9.3 & 27.0 & 12.8 & 14.3 & 8.3 & 7.8 & MS \\
A5 & $0-20$ & 13.3 & 5.7 & 7.1 & 20.7 & 14.6 & 21.4 & 11.0 & 6.2 & MS \\
A5 & $20-60$ & 9.6 & 6.8 & 8.4 & 21.5 & 15.6 & 21.2 & 10.5 & 6.2 & MS \\
A6 & $0-20$ & 36.1 & 15.3 & 12.1 & 15.7 & 7.8 & 7.2 & 3.4 & 2.1 & VCS \\
A6 & $20-60$ & 32.7 & 10.1 & 9.9 & 21.1 & 8.7 & 8.2 & 4.9 & 4.4 & VCS \\
\hline \multicolumn{1}{c}{ MS = Medium sand; VCS = Very coarse sand. According to [17]. } &
\end{tabular}

The radioactivity due to ${ }^{40} \mathrm{~K}$ in the soil samples was evaluated by gamma ray spectrometry. ${ }^{40} \mathrm{~K}$ decays directly to ${ }^{40} \mathrm{Ca}$ in the ground state through $\beta^{-}$emission $(89.3 \%)$ and also to ${ }^{40} \mathrm{Ar}$ in a $1.46 \mathrm{MeV}$ excited state followed by a prompt 1.46 $\mathrm{MeV}$ gamma emission through electron capture (10.7\%) [18]. A 2" 2 2" $\mathrm{NaI}(\mathrm{Tl})$ scintillation detector was utilized for gamma spectrometry. The spectrometric system utilizes a 2,048-channel multichannel analyzer provided by ORTEC ACE $2 \mathrm{~K}$ hardware controlled by MAESTRO software. The energy calibration of the system was performed using the radioactive sources ${ }^{137} \mathrm{Cs}(\gamma$-rays energy $=0.66$ $\mathrm{MeV})$ and ${ }^{60} \mathrm{Co}(\gamma$-rays energy $=1.17$ and $1.33 \mathrm{MeV})$ and pure powdered $\mathrm{KCl}$ $\left(52\right.$ wt. $\%$ in $\mathrm{K}$ ) as a source of ${ }^{40} \mathrm{~K}$ ( $\gamma$-rays energy $\left.=1.46 \mathrm{MeV}\right)$. The gamma spectrometer was also calibrated for yielding the ${ }^{40} \mathrm{~K}$ activity concentration on using pure powdered $\mathrm{KCl}$ and different mixtures prepared from this matrix and additions of pure $\mathrm{SiO}_{2}$. Tables 3 and 4 report all data obtained in this study. 
Table 3: Results of the chemical analyses in soil samples collected in Patrocínio Paulista, São Paulo State, Brazil.

\begin{tabular}{cccccccccccc}
\hline Sample & $\begin{array}{c}\text { Depth } \\
\text { Code }\end{array}$ & $\mathrm{SiO}_{2}$ & $\mathrm{TiO}_{2}$ & $\mathrm{Al}_{2} \mathrm{O}_{3}$ & $\mathrm{Fe}_{2} \mathrm{O}_{3}$ & $\mathrm{MnO}$ & $\mathrm{MgO}$ & $\mathrm{CaO}$ & $\mathrm{Na}_{2} \mathrm{O}$ & $\mathrm{P}_{2} \mathrm{O}_{5}$ & LOI \\
\hline $\mathrm{A} 1$ & $0-20$ & 12.31 & 9.56 & 28.64 & 29.38 & 0.11 & 0.37 & 0.13 & 0.02 & 0.66 & 18.77 \\
$\mathrm{~A} 1$ & $20-60$ & 11.97 & 9.74 & 28.86 & 29.92 & 0.11 & 0.37 & 0.11 & 0.02 & 0.61 & 18.22 \\
$\mathrm{~A} 2$ & $0-20$ & 14.24 & 9.14 & 28.62 & 29.09 & 0.12 & 0.30 & 0.23 & 0.02 & 0.56 & 17.63 \\
$\mathrm{~A} 2$ & $20-60$ & 14.16 & 9.39 & 29.58 & 30.04 & 0.12 & 0.30 & 0.17 & 0.03 & 0.49 & 15.69 \\
$\mathrm{~A} 3$ & $0-20$ & 19.73 & 8.65 & 27.73 & 27.43 & 0.11 & 0.28 & 0.15 & 0.02 & 0.42 & 15.44 \\
$\mathrm{~A} 3$ & $20-60$ & 19.36 & 8.49 & 27.65 & 27.15 & 0.09 & 0.26 & 0.07 & 0.02 & 0.29 & 16.58 \\
$\mathrm{~A} 4$ & $0-20$ & 23.39 & 7.88 & 25.54 & 24.62 & 0.09 & 0.26 & 0.22 & 0.02 & 0.55 & 17.37 \\
$\mathrm{~A} 4$ & $20-60$ & 22.27 & 8.21 & 26.40 & 25.58 & 0.09 & 0.27 & 0.12 & 0.03 & 0.40 & 16.57 \\
$\mathrm{~A} 5$ & $0-20$ & 31.60 & 7.30 & 22.46 & 24.55 & 0.12 & 0.19 & 0.03 & 0.03 & 0.19 & 13.49 \\
$\mathrm{~A} 5$ & $20-60$ & 29.93 & 7.65 & 23.64 & 24.98 & 0.10 & 0.20 & 0.03 & 0.02 & 0.19 & 13.24 \\
$\mathrm{~A} 6$ & $0-20$ & 15.33 & 9.00 & 27.90 & 27.39 & 0.09 & 0.28 & 0.19 & 0.03 & 0.48 & 19.26 \\
$\mathrm{~A} 6$ & $20-60$ & 15.79 & 9.14 & 27.88 & 28.54 & 0.10 & 0.25 & 0.07 & 0.02 & 0.38 & 17.79 \\
\hline
\end{tabular}

Table 4: Results of the analyses for total organic matter, organic carbon, $\mathrm{K}_{2} \mathrm{O},{ }^{40} \mathrm{~K}$ and exchangeable $\mathrm{K}, \mathrm{Al}$ and $\mathrm{Fe}$ in soil samples collected in Patrocínio Paulista, São Paulo State, Brazil.

\begin{tabular}{|c|c|c|c|c|c|c|c|c|c|c|c|}
\hline \multirow{3}{*}{$\mathrm{SC}^{1}$} & \multirow{3}{*}{$\begin{array}{l}\text { Depth } \\
\text { (cm) }\end{array}$} & \multirow{3}{*}{$\begin{array}{c}\mathrm{TOM}^{2} \\
(\%)\end{array}$} & \multirow{3}{*}{$\begin{array}{c}\text { Org.C } \\
(\%)\end{array}$} & \multirow{3}{*}{$\begin{array}{c}\mathrm{K}_{2} \mathrm{O} \\
(\%)\end{array}$} & \multicolumn{4}{|c|}{ Radiometric data } & \multicolumn{3}{|c|}{ Exchangeable } \\
\hline & & & & & \multirow{2}{*}{$\begin{array}{l}\text { Wt. } \\
\text { (g) }\end{array}$} & \multirow{2}{*}{$\begin{array}{l}\mathrm{CT}^{3} \\
\text { (hr.) }\end{array}$} & \multirow[t]{2}{*}{$\mathrm{TC}^{4}$} & \multirow{2}{*}{$\begin{array}{c}{ }^{40} \mathrm{~K} \\
(\mathrm{~Bq} / \mathrm{kg})\end{array}$} & $\mathrm{K}$ & $\mathrm{Al}$ & $\mathrm{Fe}$ \\
\hline & & & & & & & & & \multicolumn{3}{|c|}{$(\mathrm{mg} / \mathrm{L})$} \\
\hline A1 & $0-20$ & 5.86 & 3.41 & 0.06 & 39.4 & 22.5 & 11687 & 228.0 & 368 & 0.03 & 201.3 \\
\hline A1 & $20-60$ & 7.44 & 4.33 & 0.06 & 37.8 & 29.1 & 13576 & 215.8 & 137 & 0.00 & 171.6 \\
\hline A2 & $0-20$ & 5.12 & 2.98 & 0.05 & 39.2 & 21.9 & 11176 & 240.2 & 309 & 0.00 & 191.4 \\
\hline A2 & $20-60$ & 4.14 & 2.41 & 0.04 & 45.0 & 23.1 & 12824 & 215.8 & 406 & 0.26 & 166.1 \\
\hline A3 & $0-20$ & 4.82 & 2.80 & 0.04 & 43.9 & 24.1 & 12368 & 185.4 & 142 & 0.18 & 221.1 \\
\hline A3 & $20-60$ & 4.28 & 2.49 & 0.04 & 45.7 & 26.7 & 14603 & 237.1 & 175 & 0.20 & 206.8 \\
\hline A4 & $0-20$ & 5.32 & 3.09 & 0.07 & 42.5 & 27.0 & 15336 & 313.1 & 406 & 0.00 & 184.8 \\
\hline A4 & $20-60$ & 4.12 & 2.40 & 0.05 & 41.0 & 20.8 & 10300 & 237.1 & 295 & 0.00 & 155.1 \\
\hline A5 & $0-20$ & 3.82 & 2.22 & 0.03 & 36.9 & 23.0 & 10754 & 167.2 & 87 & 0.00 & 44.0 \\
\hline A5 & $20-60$ & 3.58 & 2.08 & 0.03 & 39.5 & 23.2 & 11170 & 115.5 & 39 & 0.00 & 125.4 \\
\hline A6 & $0-20$ & 5.56 & 3.23 & 0.04 & 43.8 & 26.5 & 14776 & 258.4 & 97 & 0.00 & 154.0 \\
\hline A6 & $20-60$ & 4.86 & 2.83 & 0.03 & 47.1 & 21.4 & 10575 & 218.9 & 56 & 0.00 & 110.0 \\
\hline
\end{tabular}

\section{The importance of weathering processes}

The soils analyzed suggest that has occurred polycyclic slow mass flow (gravitational) in the region, with accumulation of detritic concretions (lateritic/pedorelict). Such detritic flow is possibly related to the erosion of latosolized/lateralized landscapes from Lower Tertiary to Intermediary Pleistocene, which have been reworked during their evolution, forming neosols, argisols and cambisols. They can't be considered latosols and exhibit signs of previous laterization processes despite the dominance of the tropical climatic 
120 Environmental Health Risk V

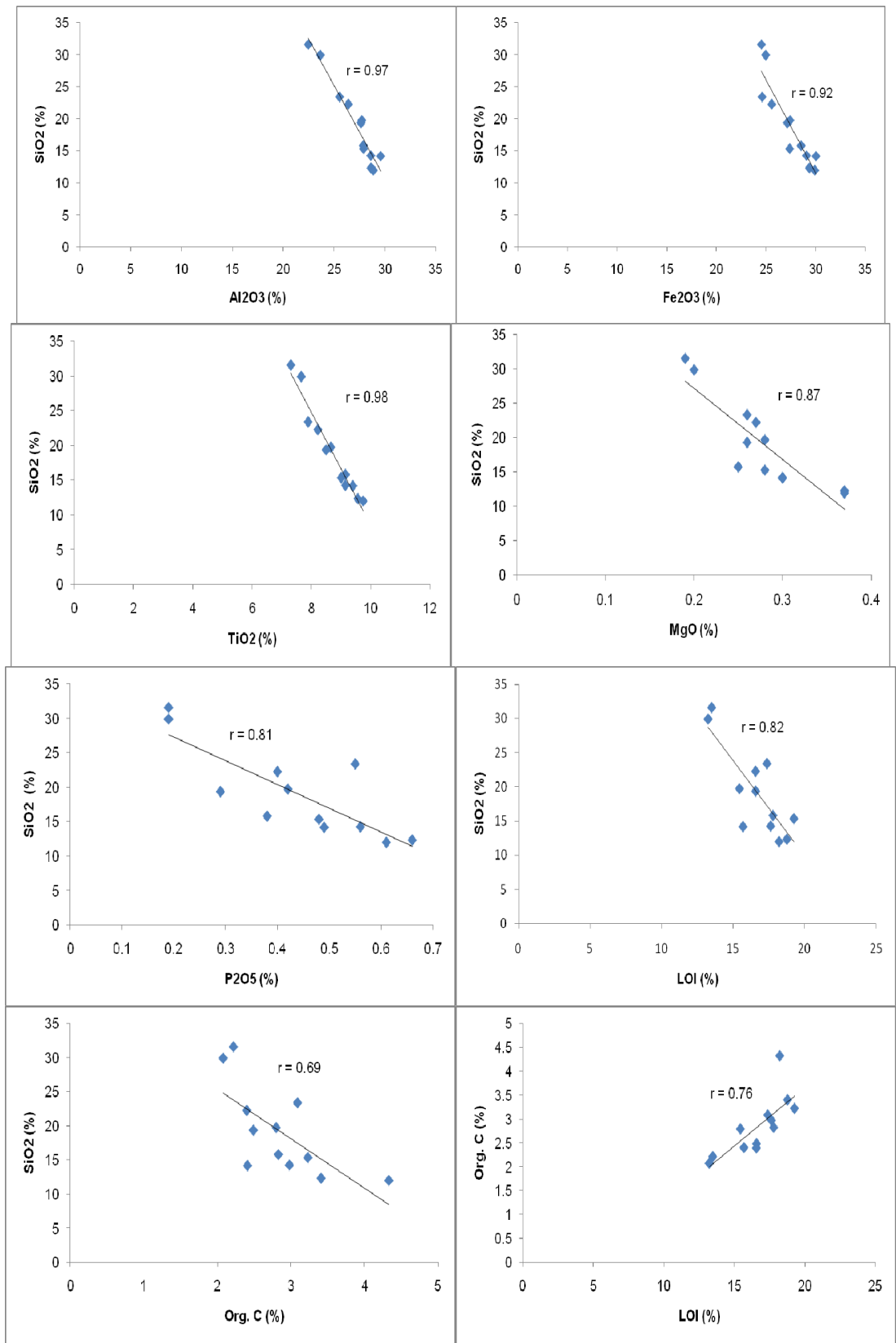

Figure 2: Relationships among $\mathrm{SiO}_{2}, \mathrm{Al}_{2} \mathrm{O}_{3}, \mathrm{Fe}_{2} \mathrm{O}_{3}, \mathrm{TiO}_{2}, \mathrm{MgO}, \mathrm{P}_{2} \mathrm{O}_{5}$, LOI and organic $\mathrm{C}$ in soil samples collected in Patrocínio Paulista, São Paulo State, Brazil. 
conditions in more recent times have favored the occurrence of ferrolysis. In lateritic soils formed by intense weathering conditions, the Si concentration may be diminished, enhancing the Al-Fe content $[19,20]$. In general, the evolution of laterization processes is related to the nature of the original rock matrix and involves all Al-silicates rock types. The chemical composition of the soils analyzed reflects at least some of these aspects, as indicated the inverse relationships among $\mathrm{SiO}_{2}, \mathrm{Al}_{2} \mathrm{O}_{3}, \mathrm{Fe}_{2} \mathrm{O}_{3}, \mathrm{TiO}_{2}, \mathrm{MgO}$ and $\mathrm{P}_{2} \mathrm{O}_{5}$ (Fig. 2).

Thus, Si-poorer sediments are more Al-Fe-Ti-Mg-P-enhanced, suggesting the occurrence of more prolonged/intense weathering processes, with the opposite also being probable. $\mathrm{Al}_{2} \mathrm{O}_{3}$ is a constituent often used to identify gains and losses during chemical weathering $[21,22]$. Such oxide is assumed to remain constant in soil profiles, despite its variability in concentration against depth [22]. $\mathrm{SiO}_{2} / \mathrm{Al}_{2} \mathrm{O}_{3}$ ratios have been utilized by geochemists as weathering indices [23, 24], with the highest values indicating less prolonged/intense processes. Beyond the typical $\mathrm{Al}_{2} \mathrm{O}_{3}-\mathrm{Fe}_{2} \mathrm{O}_{3}$ accumulations during chemical weathering, other constituents also are present in resistates/minor refractory minerals more resistant to weathering (such as apatite, zircon, and sphene, among others) that are incorporated intact in the coarser grained fraction of the soils analyzed. This could explain the direct relationships involving $\mathrm{Al}_{2} \mathrm{O}_{3}, \mathrm{Fe}_{2} \mathrm{O}_{3}, \mathrm{TiO}_{2}, \mathrm{MgO}$ and $\mathrm{P}_{2} \mathrm{O}_{5}$ (Fig. 3).

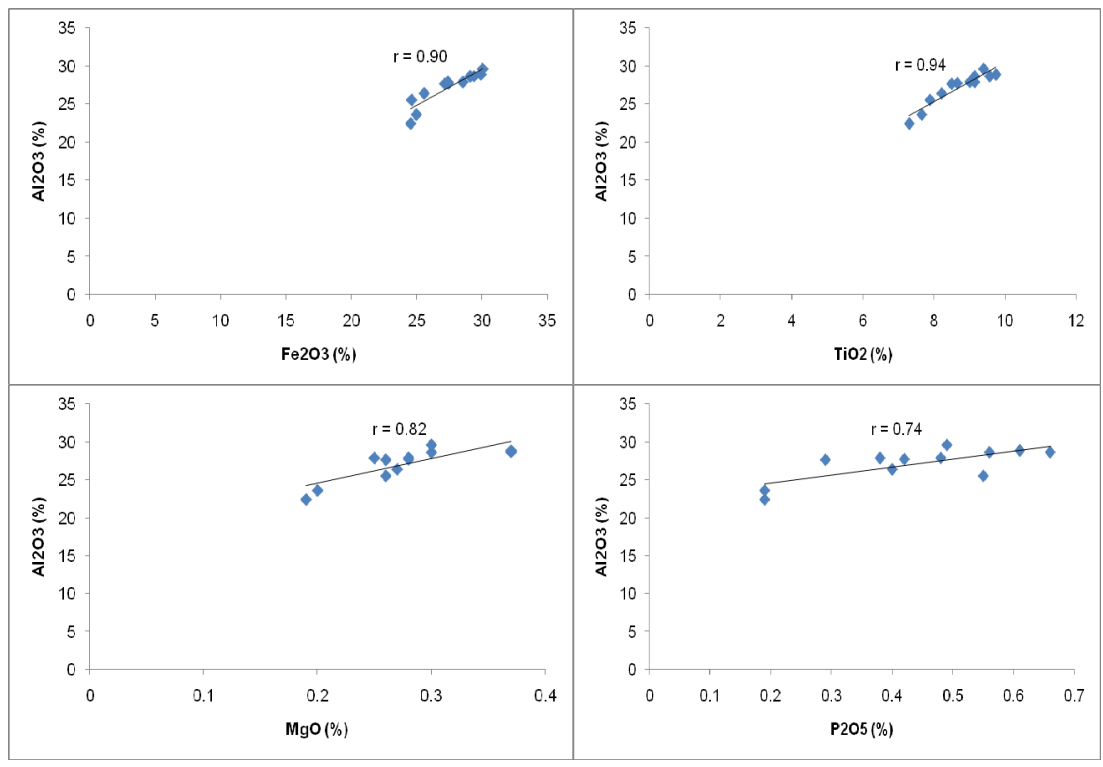

Figure 3: Relationship between $\mathrm{Al}_{2} \mathrm{O}_{3}$ and $\mathrm{Fe}_{2} \mathrm{O}_{3}, \mathrm{TiO}_{2}, \mathrm{MgO}$ and $\mathrm{P}_{2} \mathrm{O}_{5}$ in soil samples collected in Patrocínio Paulista, São Paulo State, Brazil. 
The direct relationship between LOI and organic C (Fig. 2) is related to the fact that LOI is a parameter linked to the organic matter (organic C) content of the soils. Beyond modifying the bulk density and porosity of soils, organic matter also influences their specific surface, since $1 \%$ of organic matter in porous matrices may cause an increase of the specific surface in about $7 \mathrm{~m}^{2}$ [25]. Such increase may raise the cations exchange capacity, cations adsorption, and percentage of water retention in soils. Silica is inversely related to organic matter (and organic C) at the area studied (Fig. 2), being expected that the decrease in $\mathrm{SiO}_{2}$ concentration implies on an increase of the soils specific surface.

\section{Some consequences of the vi006Easse application}

${ }^{40} \mathrm{~K}$ and $\mathrm{K}_{2} \mathrm{O}$ are directly related, as well the exchangeable potassium and $\mathrm{K}_{2} \mathrm{O}$, as expected (Fig. 4). The exposure rate, i.e. the radiation effects in the air above

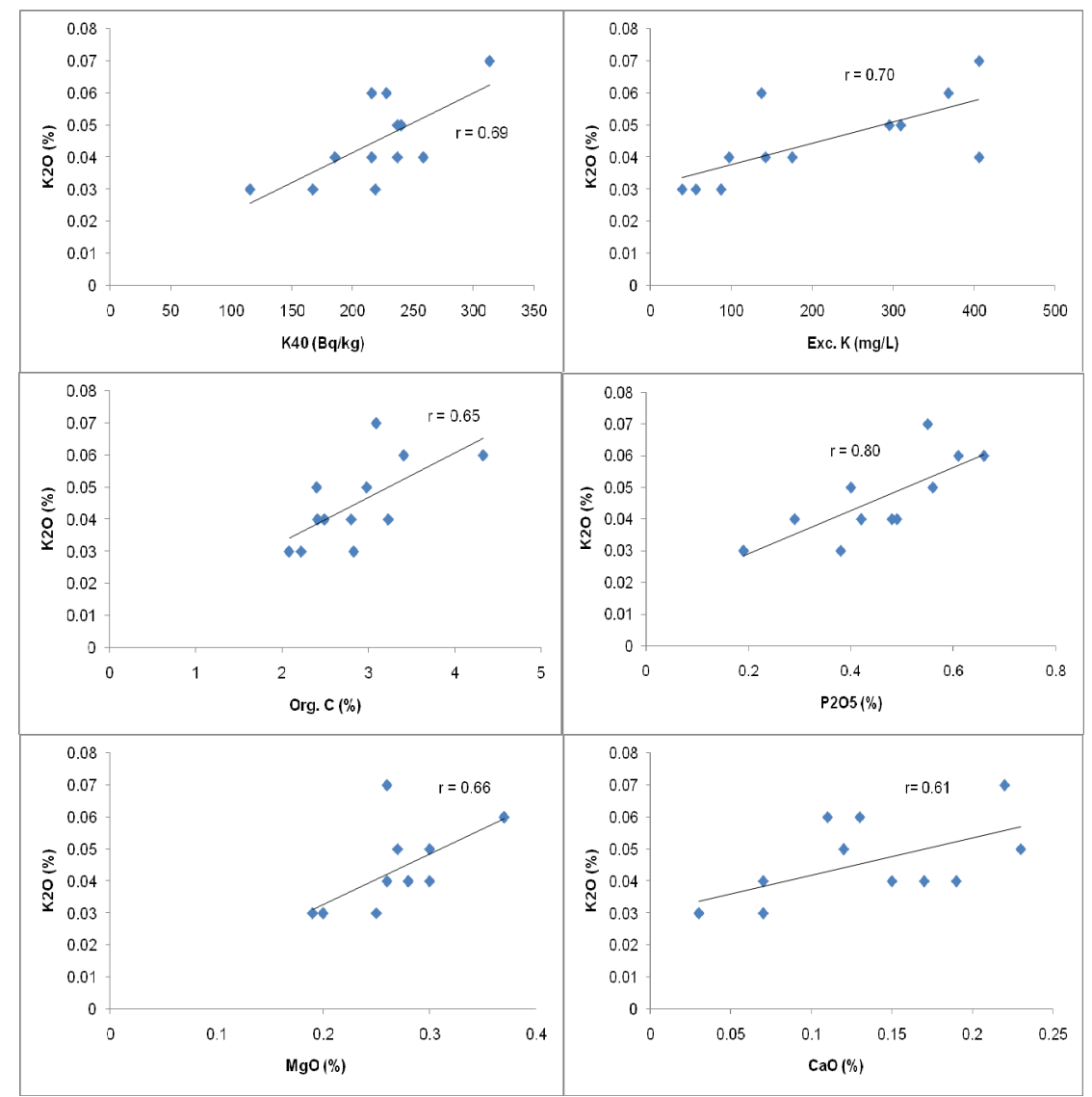

Figure 4: Relationship between $\mathrm{K}_{2} \mathrm{O}$ and ${ }^{40} \mathrm{~K}$, exchangeable $\mathrm{K}$, organic $\mathrm{C}$, $\mathrm{P}_{2} \mathrm{O}_{5}, \mathrm{MgO}$ and $\mathrm{CaO}$ in soil samples collected in Patrocínio Paulista, São Paulo State, Brazil. 
$1 \mathrm{~m}$ of the area [26], was estimated using the following dose-rate conversion factor (DRCF) to ${ }^{40} \mathrm{~K}: 0.0414 \mathrm{nGy} / \mathrm{h}$ per $\mathrm{Bq} / \mathrm{kg}$. The highest ${ }^{40} \mathrm{~K}$ activity concentration corresponded to $313 \mathrm{~Bq} / \mathrm{kg}$ (Table 4), yielding $13 \mathrm{nGyh}^{-1}$ for the exposure rate, a value that represents $24 \%$ of the world average outdoor exposure due to terrestrial gamma radiation, i.e. $55 \mathrm{nGy} / \mathrm{h}$ [26]. Thus, the radioactive impact and the external radiation exposure for population due to ${ }^{40} \mathrm{~K}$ in soils of the area studied must be minimal.

The significant relationships among $\mathrm{K}_{2} \mathrm{O}$, organic $\mathrm{C}, \mathrm{P}_{2} \mathrm{O}_{5}, \mathrm{MgO}$ and $\mathrm{CaO}$ (Fig. 4) suggest that some soil contamination may be occurring at the area studied, because vinasse has high/moderate levels of potassium, organic matter, calcium, magnesium, nitrogen and phosphorus in its chemical composition $[5,6]$. Therefore, additional investigation should be realized in the near future with the aim of evaluating the quality of the underground hydrological resources, as some vinasse constituents may be present there. In fact, the presence of $\mathrm{N}$-compounds as pollutants of groundwater resources has been identified at several monitoring wells in São Paulo State, because the nitrate and ammonium contents have greatly exceeded the limiting values, respectively, $10 \mathrm{mg} / \mathrm{L}$ and $0.5 \mathrm{mg} / \mathrm{L}$ [27]. Thus, the results here reported constitute a contribution to improve the knowledge on the consequences of the vinasse application in sugarcane fields from São Paulo State, Brazil, generating useful information for researchers/decision makers interested on its adequate management for avoiding hazards to the human health.

\section{References}

[1] Uma potência chamada São Paulo; Portal do Governo do Estado de São Paulo, Online. www.saopaulo.sp.gov.br/saopaulo

[2] Santos Associados, Região centro-sul tem 97 usinas em operação. Clipping Açúcar \& Álcool, 22, 2007.

[3] Cana, açúcar e álcool: tendência de estabilidade; John Deere, Online. www.deere.com/pt_BR/ag/veja_mais/info_mercado/sugar_cane.html

[4] Tejada, M. \& Gonzalez, J.L., Effects of two beet vinasse forms on soil physical properties and soil loss. Catena, 68, pp. 41-50, 2006.

[5] Cortez, L.A.B. \& Brossard Pérez, L.E., Experiences on vinasse disposal. Brazilian Journal of Chemical Engineering, 14 (1), pp. 1-14, 1997.

[6] Gómez, J. \& Rodríguez, O., Effects of vinasse on sugarcane (Saccharum officinarum) productivity. Rev. Fac. Agron., 17, pp. 318-326, 2000.

[7] COPERSUCAR, Aplicação de vinhaça à soqueira da cana de açúcar em tres anos consecutivos. Boletim Técnico Copersucar, 12, pp. 2-5, 1980.

[8] COPERSUCAR, Efeitos da aplicação da vinhaça como fertilizante em cana de açúcar. Boletim Técnico Copersucar, 7, pp. 9-14, 1986.

[9] García, A., Efecto de la concentración de electrolitos en el agua de riego, sobre la recuperación de suelos sódicos. Uso de vinazas. Suelos Ecuatoriales, 24, pp. 80-83, 1994.

[10] Glória, N.A. da, Utilização Agrícola da Vinhaça. Brasil Açucareiro, 86, pp. 11-17, 1975. 
[11] Silva, R.B.G., Estudo hidroquímico e isotópico das águas subterrâneas do aqüífero Botucatu no Estado de São Paulo, Ph.D. Thesis, USP-São Paulo University: São Paulo,1983.

[12] Detalhes sobre Patrocínio Paulista; Prefeitura Municipal de Patrocínio Paulista, Online. http://www.patrociniopaulista.sp.gov.br/?link=principal\&s $=$ cidade

[13] Araújo, L.M., Franca, A.B. \& Potter, P.E., Hydrogeology of the Mercosul aquifer system in the Paraná and Chaco-Parana Basins, South America, and comparison with the Navajo-Nugget aquifer system, USA. Hydrogeology Journal, 7, pp. 317-336, 1999.

[14] HACH, Water Analysis Handbook, 2 edn., Hach Company: Loveland, 1992.

[15] Boyd, C.E., Influence of organic matter on some characteristics of aquatic soils. Hydrobiologia, 36(1), pp. 17-21, 1970.

[16] Munsell, Soil color charts, Macbeth: Baltimore, 1975.

[17] Wentworth, C.K., A scale of grade and class terms for clastic sediments. Jour. Geol., 30, pp. 377-392, 1932.

[18] The Lund/LBNL Nuclear Data Search; Chu, S.Y.F., Ekström, L.P. \& Firestone, R.B., Online. http://nucleardata.nuclear.lu.se/nucleardata/toi/ index.asp

[19] Erhart, H., Itinéraires geochimiques et cycle géologique de l'aluminium. Doin: Paris, 1973.

[20] Schellmann, W., Considerations on the definition and classification of laterites. I Int. Symp. Lat. Proc., Trivandrum, pp. 1-10, 1980.

[21] Colman, S.M., Chemical weathering of basalts and andesites: evidence from weathering rinds. U.S. Geol. Surv. Prof. Paper, 1246, pp. 1-51, 1982.

[22] Faure, G., Principles and applications of inorganic geochemistry, MacMillan Publishing Co: New York, 1991.

[23] Pedro, G. \& Sieffermann, G., Weathering of rocks and formation of soils. Review in modern problems of geochemistry, UNESCO, pp. 39-55, 1979.

[24] Pedro, G., Distribution des principaux types d’alteration chimique à la surface du globe. Rev. Geogr. Phys. Géol. Dyn., X (5), pp. 457-470, 1968.

[25] Kiehl, E.J., Interpretação das propriedades dos solos, Teaching text, ESALQ-USP-São Paulo University: Piracicaba, 237 pp., 1977.

[26] UNSCEAR (United Nations Scientific Committee on the Effects of Atomic Radiation), Sources and effects of ionizing radiation. United Nations, UNSCEAR: New York, 1993.

[27] Bonotto, D.M., Caprioglio, L., Itoman, H.K., Santilli, M. \& Tessari, B.W., Hydrochemical evaluation of the quality of some Brazilian waters. Water Pollution IX: Modeling, Measuring and Prediction, eds. D. Prats Rico, C.A. Brebbia \& Y. Villacampa Esteve, WIT Press: Southampton, pp. 281293, 2008. 